\title{
PERAN PERCEIVED RESTAURANT FOOD HEALTHINESS TERHADAP PERSEPSI NILAI DAN KEPUASAN PELANGGAN: STUDI PADA RESTORAN MADAME CHANG SURABAYA
}

\author{
Vanessa Vionita Lay ${ }^{1}$, Endo Wijaya Kartika ${ }^{2 *}$ \\ ${ }^{1,2}$ Program Manajemen Perhotelan, Program Studi Manajemen, \\ Fakultas Bisnis dan Ekonomi, Universitas Kristen Petra, Surabaya

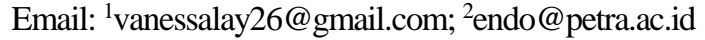 \\ *Penulis korespondensi
}

\begin{abstract}
Abstrak
Seiring dengan meningkatnya kesadaran pelanggan akan kesehatan, maka pemilihan makanan yang sehat menjadi hal yang penting untuk diperhatikan oleh restoran-restoran yang ada di Indonesia saat ini. Ketika sebuah restoran dipersepsikan memiliki menu makanan sehat maka akan memberikan persepsi nilai yang lebih bagi pelanggan dan kemudian akan menciptakan kepuasan bagi pelanggan tersebut. Penelitian ini mereplikasi model perceived restaurant food healthiness terhadap persepsi nilai dan kepuasan pelanggan dalam konteks restoran Madame Chang Surabaya, yang bertujuan untuk memberikan pembuktian empiris dalam konteks restoran di Indonesia. Penelitian ini merupakan penelitian kuantitatif kausal menggunakan data sebanyak 100 responden. Hasil menunjukkan bahwa perceived restaurant food healthiness berpengaruh positif dan signifikan terhadap persepsi nilai dan kepuasan pelanggan, sedangkan persepsi nilai berpengaruh positif dan signifikan terhadap kepuasan pelanggan.
\end{abstract}

Kata kunci: Perceived restaurant food healthiness; persepsi nilai; kepuasan pelanggan.

\begin{abstract}
Along with the increasing customers' awareness of health issues, the selection of healthy food has become an important issue to be considered by Indonesian's restaurants today. When a restaurant is perceived to have a healthy food menu, it will provide a perception of additional value to its customers; thus, it will also create satisfaction for the customers. This study replicates the perceived restaurant food healthiness model on perceived value and customer satisfaction in the context of Madame Chang Surabaya restaurant, which aims to provide an empirical evidence in the context of restaurants in Indonesia. This is a quantitative causal study using data of 100 respondents. The results showed that perceived restaurant food healthiness had a positive and significant effect on perceived value and customer satisfaction, while perceived value had a positive and significant effect on customer satisfaction.
\end{abstract}

Keywords: Perceived restaurant food healthiness; perceived value; customer satisfaction.

\section{PENDAHULUAN}

Seiring dengan munculnya usaha restoran di Indonesia, pelanggan semakin menyadari pentingnya memilih makanan dan minuman yang sehat bagi tubuh, baik dalam segi nutrisi, kesegaran dan bahan baku yang digunakan, serta memenuhi kebutuhan diet seimbang. Perilaku pelanggan ini mendorong konsumsi jenis makanan dan minuman yang alami dan sehat, seperti makanan yang mengandung sayuran dan buah-buahan, protein, dan zat-zat yang bernutrisi bagi tubuh. Pola makan tinggi lemak, tinggi kalori, dan rendah serat yang dahulu menjadi primadona mulai ditinggalkan (Permanasari dan Aditianti, 2017). Bertambahnya kesadaran masyarakat tentang menu makanan sehat mendorong pelaku usaha restoran untuk menciptakan makanan yang lezat dan menyehatkan dengan menyediakan menu bahan-bahan yang organik dan segar untuk memberikan manfaat yang dibutuhkan oleh pelanggan (Kim, Park, Ryu, \& Park, 2013).

Madame Chang Surabaya merupakan salah satu restoran di Surabaya yang memiliki konsep restaurant food healthiness. Ulasan yang menarik mengenai restoran ini yaitu adanya konsep restaurant food healthiness menjadikan restoran Madame Chang sebagai restoran sehat dengan peringkat tertinggi di Surabaya. Berdasarkan data yang didapatkan dari situs Tripadvisor per tanggal 28 Agustus 2019, diketahui bahwa Madame Chang Surabaya mendapatkan peringkat satu dari delapan restoran. Secara umum pelanggan memberikan rating 4,5 pada restoran Madame 
Chang Surabaya. Hal ini menunjukkan bahwa pelanggan memberikan tanggapan yang sangat baik pada Madame Chang Surabaya. Penilaian "sangat bagus" hingga "luar biasa" diberikan oleh pelanggan restoran berkisar antara 31\%-54\%, sementara penilaian "buruk" dan "sangat buruk" memiliki persentase yang sangat kecil yaitu antara 1\%-2\% saja. Beberapa ulasan yang diposting juga menunjukkan bahwa faktor makanan, nilai (value), layanan, serta suasana juga menunjukkan penilaian yang sangat baik. Berkaitan dengan konsep makanan sehat, Madame Chang berusaha meningkatkan citranya sebagai restoran yang berfokus pada restaurant food healthiness (www.tripadvisor.com).

Kondisi ini sebenarnya sesuai dengan semakin banyaknya restoran-restoran yang mengusung konsep sehat, dan berusaha menunjukkan label sehat pula (www.bisnisbandung.com). Banyak restoran yang mengusung konsep sehat ini menjadi sebuah potensi bisnis yang memungkinkan berkembang dengan luas khususnya pada tahun 2020 yang akan datang (Rahma, 2019). Akan tetapi apakah konsep sehat ini kemudian akan menjadi pencitraan belaka atau kemudian harus dianggap serius baik oleh pengusaha restoran maupun konsumennya, maka persepsi ini perlu untuk dikaji secara lebih mendetil.

Jun, Kang, \& Arendt (2014) menyatakan bahwa sangat penting bagi restoran untuk memperhatikan perceived restaurant food healthiness melalui menu sehat yang juga bercita rasa lezat, untuk memberikan nilai (value) positif kepada pelanggan. Perceived restaurant food healthiness mengacu pada karakteristik makanan seperti kesegaran bahan, kandungan nutrisi sehat dan faktor lainnya yang memfasilitasi makanan sehat di dalam restoran (Kim et al., 2013). Sedangkan persepsi nilai merupakan evaluasi konsumen atas perbedaan antara semua manfaat yang didapatkan dan semua biaya yang dikeluarkan relatif terhadap penawaran yang bersaing (Kotler \& Keller, 2012). Persepsi nilai merupakan faktor bisnis yang penting dan menjadi perhatian perusahaan untuk dapat mendorong kepuasan pelanggan. Dalam bidang usaha restoran persepsi nilai berkaitan dengan nilai yang dirasakan oleh pelanggan dari apa yang diberikan oleh restoran yang dapat mendorong terciptanya kepuasan khususnya ketika makanan tersebut dipersepsikan sehat melalui bahan makanan yang bergizi, sehat, organik, dan segar (Kim et al., 2013).

Namkung dan Jang (2007) menyatakan bahwa makanan sehat dapat memberikan kepuasan yang berbeda dari pelanggan, dimana pilihan makanan yang berkonsep sehat dapat memberikan kepuasan yang lebih baik. Hal ini menunjukkan bahwa terdapat hubungan positif antara persepsi makanan sehat yang dirasakan pelanggan dengan faktor kepuasan, berdasarkan fakta bahwa lebih banyak pengunjung restoran yang tertarik pada restoran yang menyajikan menu makanan sehat (Sulek dan Hensley, 2004).

Survei awal yang dilakukan kepada pelanggan Madame Chang menunjukkan beberapa hal yang dianggap menarik bahwa Madame Chang memiliki menu diet dengan nutrisi yang seimbang; memiliki kesegaran bahan baku yang baik serta organik sehingga dengan keberadaan persepsi sehat dalam menu restoran berkaitan dengan keberhasilan restoran dalam memberikan kepuasan kepada pelanggan. Penelitian ini merupakan replikasi penelitian oleh Kim et al. (2013) yang juga membahas terkait dengan perceived restaurant food healthiness, persepsi nilai, yang berdampak kepada kepuasan pelanggan, hanya saja pada penelitian ini diadopsi pada konteks restoran di kota Surabaya, yaitu restoran Madame Chang. Penelitian ini dianggap penting untuk mereplikasi model dari Kim et al. (2013) mengingat bahwa semakin tingginya tren restoran sehat, semakin paham dan adanya kebutuhan atas makanan sehat bagi konsumen, serta bagaimana persepsi ini dapat menciptakan persepsi value for money yang kemudian dapat mendorong semakin tingginya kepuasan konsumen ketika mengkonsumsi makanan sehat.

\section{TINJAUAN PUSTAKA}

\section{Perceived Restaurant Food Healthiness}

Menurut Kim et al. (2013) perceived restaurant food healthiness merupakan persepsi kesehatan dari makanan yang dirasakan pelanggan mengacu pada karakteristik makanan dan faktor-faktor yang memfasilitasi makanan sehat di dalam restoran. Makanan sehat menyiratkan produk yang utuh dan segar yang diproses dengan baik, rendah lemak, dan rendah gula, yang mana juga termasuk varian sayuran dan buah. Definisi lain dari perceived food healthiness yaitu merupakan persepsi tentang kesehatan makanan yang dikaitkan dengan jumlah kalori yang sesuai dengan kesehatan. Secara khusus, apabila dibandingkan dengan jumlah kalori sebenarnya dari makanan, pilihan makanan sehat dianggap memiliki jumlah kalori yang lebih rendah. Sedangkan makanan yang tidak sehat dianggap memiliki jumlah kalori yang lebih tinggi (Provencer, 2009). Berdasarkan definisi di atas dapat dikatakan bahwa perceived restaurant food healthiness merupakan persepsi kesehatan dari makanan yang dirasakan oleh pelanggan pada sebuah restoran yang berhubungan dengan karakteristik makanan yang diantaranya meliputi kesegaran bahan yang digunakan, kandungan rendah lemak, gula, serta kalori. 
Kim et al. (2013) menyusun atribut perceived food healthiness menjadi lima elemen penting antara lain:

1. Kandungan nutrisi yang seimbang

Porsi makanan sehat diharapkan mengandung karbohidrat, protein, lemak, vitamin, dan mineral dalam jumlah yang seimbang.

2. Ketersediaan pilihan makanan yang sesuai dengan kesehatan

Selain jumlah nutrisi, variasi makanan sangat diperlukan oleh tubuh, karena tubuh memerlukan nutrisi prebiotik yang juga bervariasi.

3. Membantu Pengontrolan diet tubuh

Ukuran porsi makanan yang di sediakan oleh restoran dapat membantu mengendalikan kebutuhan makan yang dapat mengarah kepada berat badan.

4. Informasi tentang nutrisi

Informasi nilai gizi menjadi sangat penting terutama untuk mengetahui apakah kebutuhan gizi seseorang dapat terpenuhi dengan baik dari makanan yang dikonsumsi. Dari sisi kesehatan, informasi zat gizi diperlukan khususnya bagi orang dengan kondisi kesehatan tertentu yang memerlukan pengendalian asupan zat gizi seperti misalnya pada penderita diabetes, hipertensi dan lain sebagainya.

5. Metode memasak yang sehat

Metode memasak yang sehat misalnya dikukus, direbus, dan mengurangi penggorengan dengan minyak. Kandungan lemak jenuh yang berlimpah pada minyak goreng jika digunakan secara berlebihan dan terlalu sering maka dapat meningkatkan kadar lemak berbahaya dalam tubuh.

\section{Persepsi Nilai}

Kotler dan Keller (2012) menyatakan bahwa nilai yang dirasakan adalah selisih antara penilaian pelanggan prospektif atas semua manfaat dan biaya dari suatu penawaran terhadap alternatifnya. Ditambahkan oleh Rangkuti (2006) sebagai pengkajian secara menyeluruh manfaat dari suatu produk/jasa, yang didasarkan pada persepsi pelanggan atas apa yang telah diterima oleh pelanggan dan yang telah diberikan oleh produk tersebut. Berdasarkan pengertian diatas, dapat dikatakan bahwa persepsi nilai merupakan penilaian pelanggan secara keseluruhan atas produk/jasa yang berhubungan dengan segi kemanfaatan yang dapat diambil dibandingkan dengan pengorbanan yang diberikan pelanggan.

Pada obyek restoran, (Kim et al., 2013) menggunakan tiga atribut untuk mengukur persepsi nilai, antara lain:

1. Manfaat bersantap di restoran yang sesuai dengan jumlah uang yang dikeluarkan, dimana nilai yang dirasakan pelanggan juga tergantung pada keseimbangan yang dirasakan pelanggan pada segi harga dengan semua manfaat makanan yang dikonsumsi.

2. Restoran yang menjadi pilihan terbaik jika dibandingkan dengan lainnya dalam bersantap makanan, dimana nilai yang dirasakan pelanggan juga dapat dilihat dari perbandingan dengan restoran pesaing pada aspek biaya dan aspek moneter lainnya.

3. Tingginya nilai keseluruhan dalam bersantap makanan, dimana nilai yang dirasakan pelanggan merupakan ukuran dari evaluasi secara keseluruhan pada aspek produk dan layanan yang didapatkan pelanggan.

\section{Kepuasan Pelanggan}

Zeithaml, Bitner, \& Gremler (2009) mengatakan bahwa kepuasan merupakan respon pemenuhan pelanggan, melalui penilaian bahwa fitur produk/jasa dapat menyediakan tingkat yang menyenangkan terkait pemenuhan kebutuhan. Kepuasan juga dapat diartikan sebagai perasaan senang atau kecewa seseorang yang muncul setelah membandingkan kinerja (hasil) produk yang dipikirkan terhadap kinerja (atau hasil) yang diharapkan, apabila kinerja berada di bawah harapan maka pelanggan tidak puas, sedangkan ketika kinerja memenuhi harapan maka pelanggan puas (Kotler \& Keller, 2012). Berdasarkan definisi kepuasan di atas, dapat dikatakan bahwa kepuasan merupakan perasaan senang atau kecewa atas ciri dan karakteristik produk/jasa yang muncul setelah membandingkan antara kinerja produk dan harapan pelanggan.

Huang, Yen, Liu, \& Chang (2014) mengidentifikasikan dua atribut kepuasan pelanggan yaitu:

\section{Customer Feelings}

Pengalaman yang dirasakan oleh pelanggan atas keputusan memilih produk yang mempengaruhi persepsi pada suatu merek yang pada akhirnya memiliki hubungan yang erat dengan kepuasan pelanggan.

2. Expected Performance

Layanan yang dirasakan pelanggan atas apa yang diberikan oleh perusahaan yang sesuai dengan harapan.

\section{Perceived Restaurant Food Healthiness dan Kepuasan Pelanggan}

Menurut hasil penelitian Kim et al. (2013) terindikasi bahwa perceived food healthiness dari pelanggan akan mempengaruhi kepuasan pelanggan. Pelanggan yang memperhatikan pola hidup sehat akan 
cenderung untuk memilih restoran dengan konsep yang mendukung kesehatan pelanggan. Adanya persamaan konsep sehat dari restoran yang menyediakan bahan-bahan yang bergizi, sehat, organik, dan segar dengan harapan pelanggan akan mendorong kepuasan. Semakin baik kesehatan makanan yang dirasakan pelanggan, maka semakin tinggi pula tingkat kepuasan dari pelanggan.

H1: Perceived restaurant food healthiness berpengaruh signifikan terhadap kepuasan pelanggan

\section{Perceived Restaurant Food Healthiness dan Persepsi Nilai}

Kim et al. (2013) menyatakan bahwa perceived restaurant food healthiness berpengaruh signifikan terhadap persepsi nilai. Pada usaha restoran, persepsi nilai merupakan faktor yang penting dan menjadi perhatian dari pihak restoran. Lebih lanjut menurut Kim et al. (2013) bahwa di bidang usaha restoran, persepsi nilai berkaitan dengan nilai yang dirasakan oleh pelanggan dari apa yang diberikan oleh restoran. Konsep restaurant food healthiness yang menyediakan bahan-bahan makanan restoran yang bergizi, sehat, organik, dan segar dapat mendorong evaluasi manfaat secara keseluruhan dari pelanggan. Hal ini menunjukkan kemampuan dari perceived restaurant food healthiness sebagai sebuah hal yang penting bagi peningkatan persepsi nilai dari pelanggan, serta mendorong munculnya nilai bahwa makanan sehat merupakan hal yang penting untuk dimakan (Ares \& Gambaro, 2007).

H2: Perceived restaurant food healthiness berpengaruh signifikan terhadap persepsi nilai

\section{Persepsi Nilai dan Kepuasan Pelanggan}

Kim et al. (2013) menyatakan bahwa persepsi nilai berpengaruh signifikan terhadap kepuasan. Persepsi nilai merupakan penilaian keseluruhan tentang manfaat bersantap di sebuah restoran. Menurut Kim et al. (2013) fakta bahwa lebih banyak pelanggan yang tertarik pada menu makanan sehat menunjukkan bahwa nilai-nilai makanan sehat yang dirasakan oleh pelanggan telah sesuai dengan apa yang diharapkan pelanggan, sehingga dapat mendorong kepuasan pelanggan lebih tinggi lagi terkait dengan makanan sehat yang disediakan oleh restoran. Pada konsep restoran, penelitian serupa telah berhasil dibuktikan atas pentingnya persepsi nilai terhadap kepuasan pelanggan dimana semakin tinggi sebuah makanan dipersepsikan bernilai makan secara intrinsik akan meningkatkan rasa puas dari konsumen yang memakannya (Ryu, Lee, \& Kim, 2010; Ryu, Lee, \& Gon Kim, 2012).

H3: Persepsi Nilai berpengaruh signifikan terhadap Kepuasan

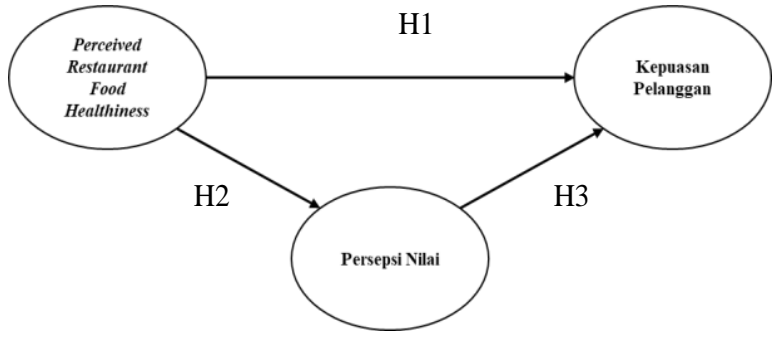

Gambar 1. Model Penelitian

\section{METODE PENELITIAN}

Penelitian ini merupakan penelitian kuantitatif kausal yang bertujuan menganalisis hubungan sebab akibat antar variabel eksogen dan endogen. Pada penelitian ini sebagai variabel eksogen adalah Perceived Restaurant Food Healthiness; sedangkan sebagai variabel endogen adalah Kepuasan Pelanggan; sedangkan Persepsi Nilai merupakan variabel endogen perantara.

Populasi pada penelitian ini meliputi seluruh pelanggan restoran Madame Chang Surabaya, dengan total sampel yang diambil sebanyak 100 orang responden. Sampel diambil dengan memperhatikan beberapa pertimbangan antara lain responden yang telah berusia diatas 17 tahun serta minimal telah 2 kali mengunjungi restoran Madame Chang Surabaya dalam kurun waktu 1 tahun terakhir. Keputusan pengambilan sampel sebesar 100 berdasarkan pertimbangan dari Hair (2010) yang mengemukakan bahwa untuk penggunaan metode Partial Least Square dibutuhkan sampel yang tidak terlalu besar yaitu antara 30 sampai dengan 100 sampel.

Penggunaan indikator pada variabel perceived restaurant food healthiness mengadopsi dari indikator yang dikemukakan oleh Kim et al. (2013) yang meliputi lima butir indikator; sedangkan untuk variabel persepsi nilai menggunakan tiga butir indikator yang diadopsi dari Kim et al. (2013); dan variabel kepuasan pelanggan digunakan tiga butir indikator yang diadopsi dari Huang et al. (2014).

\section{HASIL PENELITIAN DAN PEMBAHASAN}

Proses pengolahan data pada penelitian ini diawali dengan melakukan pengujian validitas dan reliabilitas model dengan bantuan software SmartPLS 2.0 yang sekaligus digunakan untuk pengujian hipotesis penelitian.

Berdasarkan data pada gambar 2 dan didukung pula dengan tabel 1 yang menunjukkan nilai cross loading pada data, menunjukkan bahwa seluruh loading factor memiliki nilai lebih besar dari 0.5 sehingga dapat dikatakan bahwa seluruh indikator yang digunakan sebagai variabel manifes adalah valid. 


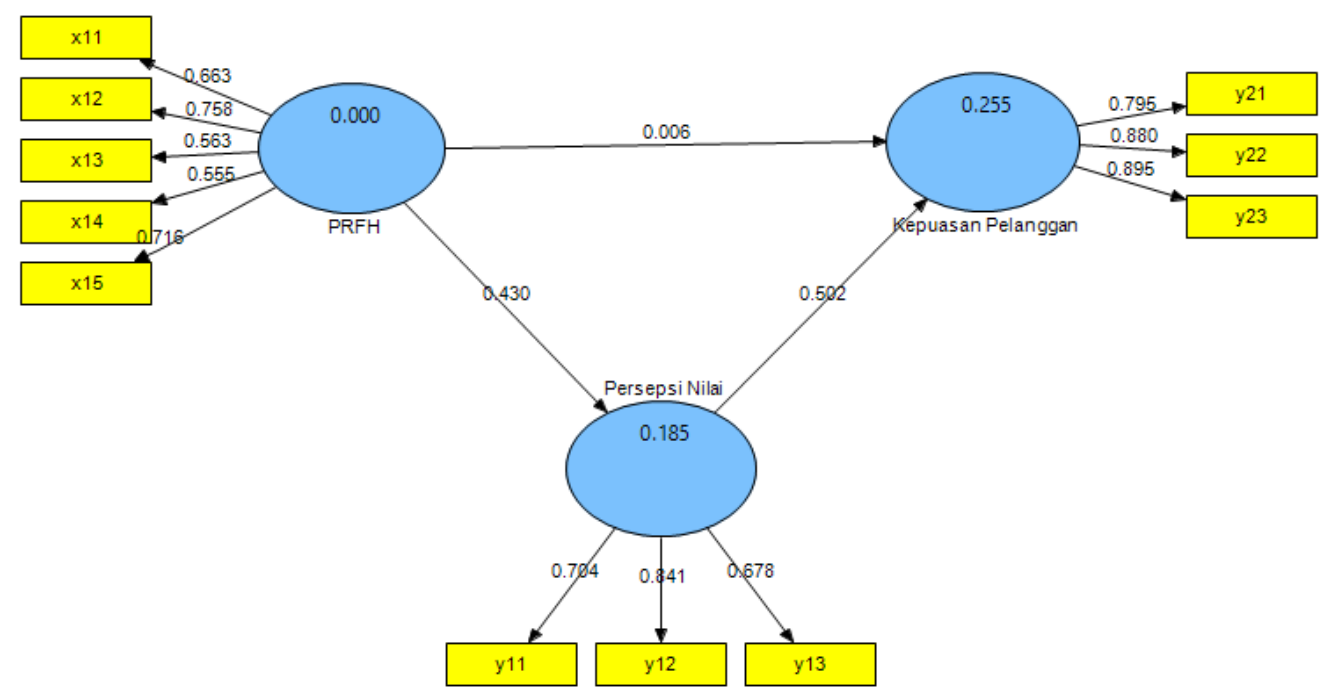

Gambar 2. Model Awal Penelitian

Tabel 1. Nilai Cross Loading

\begin{tabular}{cccc}
\hline & $\begin{array}{c}\text { Kepuasan } \\
\text { Pelanggan }\end{array}$ & $\begin{array}{c}\text { Perceived Food } \\
\text { Healthiness }\end{array}$ & $\begin{array}{c}\text { Persepsi } \\
\text { Nilai }\end{array}$ \\
\hline x11 & 0.167 & $\mathbf{0 . 6 6 3}$ & 0.300 \\
x12 & 0.229 & $\mathbf{0 . 7 5 8}$ & 0.264 \\
x13 & 0.213 & $\mathbf{0 . 5 6 3}$ & 0.240 \\
x14 & -0.021 & $\mathbf{0 . 5 5 5}$ & 0.261 \\
$\mathbf{x 1 5}$ & 0.094 & $\mathbf{0 . 7 1 6}$ & 0.342 \\
y11 & 0.317 & 0.270 & $\mathbf{0 . 7 0 4}$ \\
y12 & 0.486 & 0.341 & $\mathbf{0 . 8 4 1}$ \\
y13 & 0.296 & 0.348 & $\mathbf{0 . 6 7 8}$ \\
y21 & $\mathbf{0 . 7 9 5}$ & 0.209 & 0.446 \\
y22 & $\mathbf{0 . 8 8 0}$ & 0.147 & 0.378 \\
y23 & $\mathbf{0 . 8 9 5}$ & 0.207 & 0.462 \\
\hline
\end{tabular}

Langkah selanjutnya yang dilakukan adalah melakukan pengujian reliabilitas pada masing-masing variabel yang diteliti. Untuk menunjukkan bahwa variabel pada penelitian adalah reliabel dengan melihat hasil akar AVE; composite reliability; dan cronbach's alpha. Nilai pada masing-masing reliabilitas diharapkan lebih besar sama dengan 0.6 untuk akar AVE dan cronbach's alpha; sedangkan untuk composite reliability nilai lebih besar dari 0.7 sebagai batas bawah dikatakan reliabel.

Tabel 2. Nilai Reliabilitas

\begin{tabular}{|c|c|c|c|}
\hline & $\sqrt{ } \mathbf{A V E}$ & $\begin{array}{l}\text { Composite } \\
\text { Reliability }\end{array}$ & $\begin{array}{c}\text { Cronbachs } \\
\text { Alpha }\end{array}$ \\
\hline $\begin{array}{l}\text { Kepuasan Pelanggan } \\
\text { Perceived Food }\end{array}$ & 0.858 & 0.893 & 0.819 \\
\hline Healthiness & 0.656 & 0.788 & 0.665 \\
\hline Persepsi Nilai & 0.744 & 0.787 & 0.596 \\
\hline
\end{tabular}

Berdasarkan data dari tabel 2, didapatkan bahwa keseluruhan nilai akar AVE dan cronbach's alpha lebih besar sama dengan 0.6 dan composite reliability memiliki nilai lebih besar dari 0.7 sehingga dapat dikatakna bahwa keseluruhan variabel pada penelitian ini adalah reliabel.

Tabel 3. Uji Hipotesis

\begin{tabular}{lc}
\hline & T Statistics \\
\hline $\begin{array}{l}\text { Perceived Food Healthiness } \rightarrow \text { Kepuasan } \\
\text { Pelanggan }\end{array}$ & 2.1317 \\
Perceived Food Healthiness $\rightarrow$ Persepsi & 5.6721 \\
Nilai & \\
Persepsi Nilai $\rightarrow$ Kepuasan Pelanggan & 5.5865 \\
\hline
\end{tabular}

Pengujian hipotesis dilakukan dengan membandingkan nilai $\mathrm{t}$ statistik atas hasil pengolahan data dengan nilai $t$ tabel yang didapatkan pada nilai alpha 5\% yaitu 1.96 sehingga hipotesis didukung apabila nilai t statistik menunjukkan hasil lebih besar dari 1.96 sebagai nilai $\mathrm{t}$ tabel. Pada tabel 3 didapatkan hasil bahwa perceived food healthiness berpengaruh secara positif dan signifikan terhadap kepuasan pelanggan serta persepsi nilai, sehingga hipotesis 1 dan 2 didukung. Sedangkan persepsi nilai berpengaruh secara positif dan signifikan terhadap kepuasan pelanggan sehingga hipotesis 3 juga didukung, oleh karena itu pada penelitian ini seluruh hipotesis yang diajukan dapat didukung.

Hasil penelitian ini turut mendukung hasil studi terdahulu yang dilakukan oleh Kim et al. (2013); Namkung \& Jang (2007) yang menyatakan bahwa semakin tinggi persepsi makanan dianggap sehat dapat meningkatkan persepsi nilai serta tingkat kepuasan dari 
pelanggan. Pada konteks restoran Madame Chang Surabaya, perceived food healthiness direfleksikan melalui restoran Madame Chang menyediakan pilihan makanan sehat. Dengan adanya pilihan makanan sehat yang ditawarkan, bagi pelanggan yang memperhatikan pola hidup sehat akan cenderung lebih merasa sesuai dengan apa yang diharapkan, atau dengan kata lain ketika yang menjadi kebutuhan dari pelanggan adalah makanan yang dibuat dari bahan-bahan yang bergizi, sehat, dan segar akan semakin meningkatkan kesesuaian pelanggan untuk mengkonsumsi makanan sehat dengan baik maka secara langsung dapat meningkatkan kepuasannya pula (Kim et al., 2013).

Pada penelitian ini, perceived food healthiness juga mampu memberikan dampak terhadap terciptanya persepsi nilai bagi pelanggan. Hasil penelitian ini turut mendukung pula studi yang dilakukan oleh Kim et al. (2013). Persepsi nilai pada konteks restoran Madame Chang Surabaya direfleksikan melalui indikator mengkonsumsi makanan sehat merupakan pilihan yang terbaik dibandingkan restoran lainnya. Dengan kata lain persepsi nilai yang muncul dari penyediaan menu makanan sehat yang ditawarkan restoran Madame Chang dapat meyakinkan pelanggan sebagai pilihan terbaik dibandingkan dengan restoran lainnya. Seringkali pelanggan memerlukan pertimbangan atas pentingnya makanan yang diolah secara baik dengan bahan yang bergizi dan segar, pertimbangan manfaat yang dapat dirasakan melalui pilihan makanan sehat tersebut dapat meningkatkan persepsi bahwa makanan yang ditawarkan merupakan pilihan terbaik dibandingkan makanan yang ditawarkan oleh restoran lain, sehingga dapat dikatakan bahwa semakin tinggi makanan dipersepsikan sebagai makanan sehat maka dapat meningkatkan persepsi nilai lebih yang didapatkan dari makanan tersebut (Kim et al., 2013).

Hasil penelitian ini juga membuktikan bahwa persepsi nilai dapat memberikan dampak positif terhadap peningkatan kepuasan pelanggan. Dalam konteks restoran Madame Chang Surabaya, nilai-nilai yang dimunculkan dari makanan sehat dapat menciptakan kesesuaian persepsi dan harapan pelanggan yang menginginkan makanan sehat sebagai menu yang ditawarkan, sehingga dengan terciptanya nilainilai yang dapat memberikan manfaat lebih bagi pelanggannya dapat meningkatkan kesesuaian apa yang diharapkan oleh pelanggan yang kemudian menimbulkan kepuasan atas apa yang telah didapatkan dari menu makanan sehat tersebut (Kim et al., 2013).

\section{SIMPULAN DAN SARAN}

Pada penelitian ini dapat disimpulkan bahwa perceived restaurant food healthiness dapat berpengaruh secara positif dan signifikan terhadap kepuasan pelanggan dan persepsi nilai, sedangkan persepsi nilai dapat berpengaruh secara positif dan signifikan terhadap kepuasan pelanggan. Penelitian ini sekaligus menjadi pembuktian model yang dikembangkan oleh Kim et al. (2013) yang diterapkan dalam konteks restoran Madame Chang Surabaya.

Saran yang dapat diberikan kepada restoran Madame Chang Surabaya bahwa dengan adanya menu makanan sehat yang ditawarkan saat ini dapat menciptakan kesesuaian atas harapan pelanggan yang ingin hidup sehat, akan tetapi alangkah baiknya ketika makanan setelah dipersepsikan oleh pelanggan adalah sehat dan kemudian dapat memberikan nilai tambah yang lebih dibandingkan restoran lain, makan akan terbentuk sebuah persepsi bahwa dengan memilih makanan sehat yang ditawarkan oleh restoran Madame Chang Surabaya merupakan sebuah keputusan yang paling tepat sehingga dapat lebih memberikan keyakinan kepada pelanggan atas manfaat yang dapat dirasakan ketika mengkonsumsi makanan sehat.

\section{DAFTAR REFERENSI}

Ares, G., \& Gámbaro, A. (2007). Influence of gender, age and motives underlying food choice on perceived healthiness and willingness to try functional foods. Appetite, 49(1), 148-158.

Bisnisbandung. (2018). Sukses mengusung konsep sehat di resto fastfood. Retrieved from http://bisnisbandung.com/2018/07/21/suksesmengusung-konsep-sehat-di-resto-fastfood/

Hair, J. F. (2010). Multivariate data analysis. New Jersey: Pearson Education Inc.

Huang, C. C., Yen, S. W., Liu, C. Y., \& Chang, T. P. (2014). The relationship among brand equity, customer satisfaction and brand resonance to repurchase intention of cultural and creative industries in taiwan. The International Journal of Organizational Innovation. 6(3). 106-120.

Kim, H. J., Park, J., Ryu, K., \& Park, J. (2013). Does perceived restaurant food healthiness matter? Its influence on value, satisfaction and revisit intentions in restaurant operations in South Korea. International Journal of Hospitality Management. 33. 397- 405.

Kotler, P., \& Keller, K. L. (2012). Manajemen Pemasaran. Jakarta: PT. Erlangga.

Namkung, Y., \& Jang, S. (2007). Does food quality really matter in restaurant? Its impact on customer satisfaction and behavioral intentions. Journal of Hospitality and Tourism Research. 31 (3). 387410.

Permanasari, Y., \& Aditianti. (2017). Konsumsi makanan tinggi kalori dan lemak tetapi rendah 
serat dan aktivitas fisik kaitannya dengan kegemukan pada anak usia 5-18 tahun di Indonesia. Penelitian Gizi dan Makanan. 40 (2). 95- 104.

Provencer, V. (2009). Perceived healthiness of food. if it's healthy, you can eat more. Appetite. 52. 340344.

Rahma, E. (2019). Makanan sehat jadi tren restoran tahun 2020. Marketeers. Retrived from https://marketeers.com/makanan-sehat-jaditren-restoran-tahun-2020/

Rangkuti, F. (2006). Riset pemasaran. Jakarta : PT. Gramedia Pustaka Utama.

Ryu, K., Han, H., \& Jang, S. (2010). Relationships among hedonic and utilitarian values, satisfaction and behavioral intentions in the fast-casual restaurant industry. International Journal of Contemporary Hospitality Management, 22(3), 416432.
Ryu, K., Lee, H. R., \& Gon Kim, W. (2012). The influence of the quality of the physical environment, food, and service on restaurant image, customer perceived value, customer satisfaction, and behavioral intentions. International Journal of Contemporary Hospitality Management, 24(2), 200-223.

Sulek, J. M., \& Hensley, R. L. (2004). The relative importance of food, atmosphere, and fairness of wait: the case of a full-service restaurant. Cornell Hotel and Restaurant Administration Quarterly. 45 (3). 235-247.

Tripadvisor. (2019, Juni Kamis). Madame Chang, Surabaya- Ulasan Restoran. Retrieved from Trip Advisor: https://www.tripadvisor.co.id/Restaurant_Review-g299715-d3653999-ReviewsMadame_Chang-Surabaya_East_Java_Java.html

Zeithaml, V. A., Bitner, M. J., \& Gremler, D. D. (2009). Services marketing: integrating customer focus across the firm. McGraw- Hill Companies, Inc. 